\title{
GREEN SYNTHESIS OF SILVER NANOPARTICLES USING MANGROVE FRUIT POLYSACCHARIDE FOR BACTERIAL GROWTH INHIBITION
}

\author{
GAJENDRA NATH MAITY ${ }^{1 *}$, JOY SARKAR ${ }^{2,3}{ }^{\text {, }}$, SOMANJANA KHATUA ${ }^{2,4}$, SOUMITRA MONDAL $^{5}$ \\ KRISHNENDU ACHARYA ${ }^{2,6 *}$
}

\begin{abstract}
${ }^{1}$ Department of Microbiology, Panskura Banamali College, Purba Medinipur, West Bengal, India. ${ }^{2}$ Department of Botany, Molecular and Applied Mycology and Plant Pathology Laboratory, Centre of Advanced Study, University of Calcutta, Kolkata, West Bengal, India. ${ }^{3}$ Department of Botany, Dinabandhu Andrews College, Kolkata, West Bengal, India. ${ }^{4}$ Department of Botany, Krishnagar Government College, Krishnagar, Nadia, West Bengal, India. ${ }^{5}$ Department of Chemistry, Panskura Banamali College, Panskura R.S., Purba Medinipur, West Bengal, India. ${ }^{6}$ Center for Research in Nanoscience and Nanotechnology, Technology Campus, University of Calcutta, Kolkata, West Bengal, India. *Email: krish_paper@yahoo.com
\end{abstract}

${ }^{\ddagger}$ These authors have contributed equally to this work.

Received: 21 April 2019, Revised and Accepted: 21 May 2019

ABSTRACT

Objective: The objective of this study was to find out the antibacterial activity of the silver nanoparticles (Ag-NPs) using a low-cost green synthesis approach for the formulation of Ag-NPs applying polysaccharide extracted from the fruits of a mangrove plant of Sundarban.

Methods: Fresh and healthy fruits were collected from Ceriops decandra plant. Sufficient amount of carbohydrates was extracted from those fruits and the physicochemical characterization of the polysaccharide was analyzed by gas chromatography-mass spectrometry and Fourier-transform infrared spectrophotometry. The respective polysaccharide was further applied to generate the Ag-NPs which were characterized by UV visible, dynamic light scattering, transmission electron microscopy, EDAX, and X-ray diffraction. The antibacterial efficacy of the Ag-NPs was also determined against some pathogenic Gram-negative and Gram-positive bacteria using the microdilution method.

Results: Glucose and galactose are the major monomers among the extracted carbohydrates. Various types of spectral analysis confirmed the formation of Ag-NPs. The green synthesized Ag-NPs have the average diameter of about $28 \mathrm{~nm}$. Furthermore, the green synthesized Ag-NPs exhibited strong antibacterial activity against some pathogenic Gram-positive (L. cytomonogenes, Bacillus Subtilis, and Staphylococcus aureus) and Gramnegative (Salmonella typhimurium and Escherichia coli) bacteria.

Conclusion: The green synthesis of Ag-NPs using plant polysaccharide was an environment-friendly and cost-effective method as compared to the conventional physical and chemical synthesis techniques.

Keywords: Green synthesis, Ceriops decandra, Polysaccharide, Silver nanoparticle, Bacterial growth.

(c) 2019 The Authors. Published by Innovare Academic Sciences Pvt Ltd. This is an open access article under the CC BY license (http://creativecommons. org/licenses/by/4. 0/) DOI: http://dx.doi.org/10.22159/ajpcr.2019.v12i7.33681

\section{INTRODUCTION}

Since 1000 B.C., Ag has been applied for the treatment of burns, wounds, and several bacterial infections in the form of metallic silver, silver nitrate $\left(\mathrm{AgNO}_{3}\right)$, as well as silver sulfadiazine. However, the use of silver compounds in medicinal systems declined to a great extent after the introduction of penicillin during the 1940s [1]. However, over the recent past, the field of nanotechnology has introduced a new era of science which involves the creation of materials nearatomic scale with unique chemical, physical, thermal, and optical properties [2]. As a consequence, metallic silver made a remarkable comeback in the form of Ag-NP with powerful antimicrobial effects. Investigations have revealed that after exposure to bacteria, the nano-silver gets attached to the cell membrane, penetrates inside, and attacks respiratory chain that ultimately leads to cell death. In addition, these particles release silver ions inside cells which inhibit bacterial replication ability and cause the deactivation of proteins containing thiol groups $[1,3]$. This has unfolded novel strategies to use pure silver against a wide range of antibiotic-resistant microorganisms, and as a result, it has been adopted in many commercial products such as topical ointments, toothpaste, soap, and socks $[4,5]$. In addition, Ag-NP has also emerged up as a promising agent for wastewater purification system [6]. In recent work, the use of silver compounds as antimicrobial compounds against coliform bacteria found in wastewater has been reported [7].
So far, a number of techniques are available for Ag-NP synthesis; although most of them are expensive, complicated, and involve the use of hazardous chemicals [8]. Conversely, the biological techniques are considered as an alternative and advancement over other methods as it involves natural reagents such as sugars, biodegradable polymers, plant extracts, and microorganisms [4,9-19]. In this context, the mangrove plant, Ceriops decandra (Griff.) W. Theob., could be an effective alternative as it was scientifically proved to contain several bioactive components. It has been traditionally used as remedial measures for hepatitis, diabetes, wounds, ulcers, boils, angina, dysentery, and diarrhea [20-23]. Recent investigations have reported that $C$. decandra possesses antioxidant [24], antinociceptive [25], antidiabetic [26], and antimicrobial properties [27-30]. Thus, the present work was aimed for the synthesis of Ag-NP by a greener method using polysaccharide extracted from fruits of $C$. decandra, characterization of the particles, and assessment of antibacterial efficacy against some pathogenic microorganisms.

\section{MATERIALS AND METHODS}

\section{Plant material}

The plant parts of $C$. decandra (Griff.) W. Theob. were collected from the mangrove forest of Sundarban $\left(21.9497^{\circ} \mathrm{N}, 89.1833^{\circ} \mathrm{E}\right)$ of the district South 24 Parganas, West Bengal, India. The respective plant specimen was self-identified and binomially jointly by the Department of Botany, 
University of Calcutta, West Bengal - 700 019, India and Department of Botany, Dinabandhu Andrews College, Garia, Kolkata - 700 084, West Bengal, India. Voucher specimens were made from the collected specimen and further deposited at the Herbarium of the Botany Department, Dinabandhu Andrews College.

\section{Isolation of polysaccharide from fruits of $\boldsymbol{C}$. decandra}

Fresh and healthy fruits were collected from the respective mangrove plant. To remove all noticeable unwanted as well as dust particles, the fruits were washed carefully with tap water followed by distilled water. After that, they were dried at room temperature and cut into small pieces. About $750 \mathrm{~g}$ of these finely incised fruits were steeped into $250 \mathrm{ml}$ distilled water and boiled for $5 \mathrm{~h}$. The resultant solution was maintained at $4{ }^{\circ} \mathrm{C}$ for overnight and then filtered through nylon cloth. Polysaccharides were precipitated by adding five volume of absolute ethanol and incubated overnight at $4^{\circ} \mathrm{C}$. After centrifugation at $8000 \mathrm{rpm}$ for $10 \mathrm{~min}$, the precipitate was again dissolved in distilled water and dialyzed through DEAE cellulose bag for $2 \mathrm{~h}$ to remove lowmolecular-weight polysaccharides. Further, the lyophilized extract was subjected to Sephadex G-100 gel permeation column $(50 \mathrm{~cm} \times 1.5 \mathrm{~cm})$ using water as eluent (flow rate: $0.5 \mathrm{ml} / \mathrm{min}$ ). The eluate was collected ( $2 \mathrm{ml} /$ tube) and carbohydrates were determined by the phenol-sulfuric acid method [31,32]. Finally, polysaccharide was pooled from test tube number 15-30 and vacuum freeze-dried.

\section{Physicochemical characterization of polysaccharide}

The total quantity of sugar was measured by the phenol-sulfuric acid method using glucose as standard. The protein content was estimated by Bradford using bovine serum albumin as a reference. Gallic acid was considered as a standard to quantify the total amount of phenolic compounds present in the polysaccharide using Folin-Ciocalteu reagent. All values were presented as a gram of standard equivalents per $100 \mathrm{~g}$ of dry polysaccharide [33]. For determination of monosaccharide composition, $2 \mathrm{mg}$ polysaccharide was hydrolyzed with $2 \mathrm{M}$ TFA at $100^{\circ} \mathrm{C}$ for $2 \mathrm{~h}$ in screw cap vial. TFA was eliminated by evaporation at $55^{\circ} \mathrm{C}$ under reduced pressure (Rota vapor R3, Buchi, Switzerland). About $50 \%$ ethanol $(1 \mathrm{ml})$ was included in the vial to dissolve hydrolysate. The solution was centrifuged ( $5 \mathrm{~min}, 12,000 \mathrm{rpm}$ ) to remove non-hydrolyzed polysaccharide and further analyzed by gas chromatography-mass spectrometry (GC-MS) as described in our previous publication [34]

\section{Green synthesis of silver nanoparticles (Ag-NPs)}

$\mathrm{AgNO}_{3}(>99.9 \%$ pure) was purchased from Merck, India. For Ag-NP synthesis, $20 \mathrm{ml}$ of $0.5 \mathrm{mg} / \mathrm{ml}$ of isolated polysaccharide was mixed with $20 \mathrm{ml}$ of $1 \mathrm{mM} \mathrm{AgNO}{ }_{3}$ solution and stirred with a magnetic stirrer for $90 \mathrm{~min}$ at room temperature. Change of color from pale yellow to brown specified the production of the Ag-NP due to the reaction of polysaccharide with the silver metal ion. Simultaneously, both the positive control (polysaccharide solution without any addition of $\mathrm{AgNO}_{3}$ ) and the negative control (only the $\mathrm{AgNO}_{3}$ solution) sets were kept under the same conditions, in which the reaction mixture was maintained.

\section{Characterization of synthesized Ag-NPs}

Generation of Ag-NP was established by UV-visible (UV-Vis) spectrophotometer (Hitachi 330 spectrophotometer) with plasmon peaks at different regions of the spectral range 200-900 nm which corresponded to differentsignature marks for the production of different nanoparticles (NPs), respectively. Particle size was determined using Zen 1600 Malvern nanosize particle analyzer ranging between $0.6 \mathrm{~nm}$ and $6.0 \mu \mathrm{m}$. For X-ray diffraction (XRD) measurement of the reaction mixture, the spectra were recorded in a PW 3040/60 PANalytical X-ray Diffractometer ( $\mathrm{Cu} \mathrm{K \alpha}$ radiation, $\lambda$ 1.54443) running at $45 \mathrm{kV}$ and $30 \mathrm{~mA}$. The diffracted intensities were documented from $35^{\circ}$ to $90^{\circ}$ $2 \theta$ angles. Energy-dispersive X-ray (EDX) analysis of the dried sample of Ag-NP was carried out by the Hitachi S $3400 \mathrm{~N}$ instrument. For Fourier transform infrared (FTIR) analysis, the dried Ag-NP was mixed with potassium bromide $(\mathrm{KBr})$ at a ratio of 1:100. Furthermore, the prepared pellet was observed using a diffuse reflectance accessory in the spectral range between 4000 and $400 / \mathrm{cm}$ with a Shimadzu $8400 \mathrm{~S}$
FTIR spectrophotometer. In addition, the synthesized particles were studied and visualized by transmission electron microscopy (TEM) using Tecnai G2 spirit Biotwin instrument (FP 5018/40), operating at around $80 \mathrm{kV}$ accelerating voltage.

\section{Analysis of the effect of synthesized Ag-NPs on some pathogenic} bacteria

Bacillus subtilis ATCC $^{\circledR} 6633^{\text {TM }}$ (MTCC 736), Listeria monocytogenes ATCC $^{\circledR} 19111^{\text {TM }}$ (MTCC 657), Staphylococcus aureus ATCC ${ }^{\circledR} 700699^{\text {TM }}$, Escherichia coli ATCC $^{\circledR} 25922^{\mathrm{TM}}$, and Salmonella typhimurium ATCC $^{\circledR}$ $23564^{\mathrm{TM}}$ (MTCC 98) were utilized for the experiment. The antibacterial effect was estimated by determining minimum inhibitory concentration (MIC) values according to the microdilution method [35]. The six investigating bacteria were cultured freshly and $1 \times 10^{5} \mathrm{CFU} / \mathrm{ml}$ concentrated dilutions were prepared separately. Reactions were performed in 96-well plates consisting of $200 \mu \mathrm{l}$ of NB, $20 \mu \mathrm{l}$ of inoculum, and different dilutions of NPs. Following incubation for 1 day at $37^{\circ} \mathrm{C}, 40 \mu \mathrm{l}$ of INT dye $(0.2 \mathrm{mg} / \mathrm{ml})$ was added and incubated for another $30 \mathrm{~min}$. The concentration that inhibited $50 \%$ growth of bacteria as compared with positive control was calculated as MIC value. Streptomycin was used as a standard drug.

\section{RESULTS AND DISCUSSION}

Physicochemical characterization of isolated polysaccharide

The extractive yield of polysaccharide from fruits of $C$. decandra was $0.002 \%$ of dry matter. Total carbohydrate and protein content of the polysaccharide was $53.06 \pm 2.73 \mathrm{~g} / 100 \mathrm{~g}$ and $5.04 \pm 0.31 \mathrm{~g} / 100 \mathrm{~g}$ of dry polysaccharide, respectively. A very negligible amount of phenolics was detected $(0.005 \pm 0.001 \mathrm{~g} / 100 \mathrm{~g}$ of dry polysaccharide). Further, the composition of molecular components was determined by GC-MS where two monosaccharides such as glucose as well as galactose were detected in a molar ratio of 3.64:1 (Fig. 1).

\section{Green synthesis of Ag-NP}

The characteristic brown color of the reaction mixture, a signature mark for the production of Ag-NP in the solution, arose due to the collective vibration of free electrons of Ag-NP in resonance with a light wave. The surface plasmon resonance absorption band of the reaction solution in the visible spectral region of electromagnetic radiation further confirmed the claim of the formation of Ag-NP [36]. The synthesis of Ag-NP by reduction of the metal ions during exposure of $20 \mathrm{ml}$ of $0.5 \mathrm{mg} / \mathrm{ml}$ of the polysaccharide isolated from C. decandra into $20 \mathrm{ml}$ of $1 \mathrm{mM} \mathrm{AgNO}_{3}$ solution detected by brown color formation (Fig. 2).

UV/Vis spectrophotometric analysis of biosynthesized Ag-NP The reduction of silver from $\mathrm{Ag}+$ ions to $\mathrm{Ag}^{0}$ state was subjected to spectral analysis. The surface plasmon band of the reaction mixture

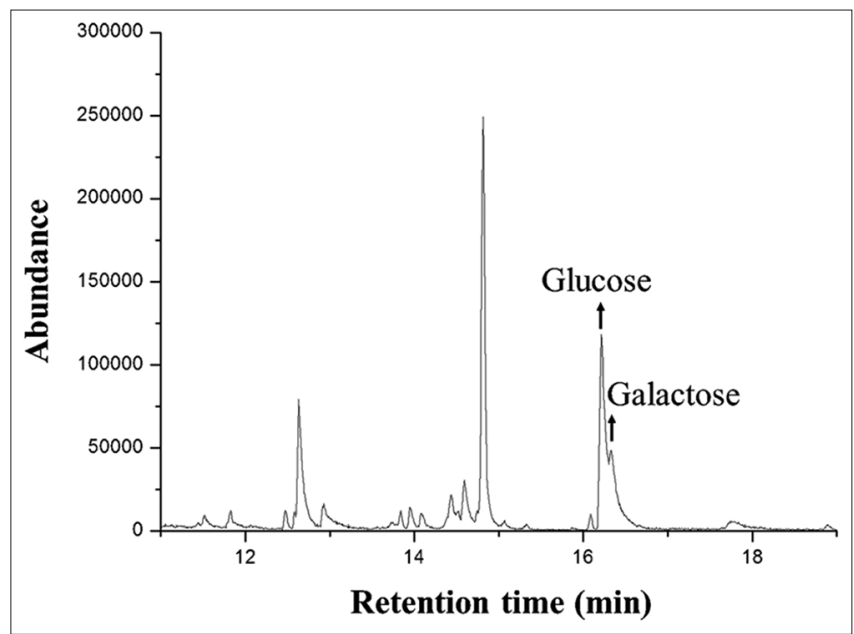

Fig. 1: Gas chromatography-mass spectrometry of polysaccharide extracted from fruits of Ceriops decandra 
was obtained in the visible region at $426 \mathrm{~nm}$, which was specific for Ag-NP (Fig. 3). Furthermore, this spectral analysis suggested that the NPs were well dispersed in the solution as well as there was not any type of indication for the aggregation of the NPs.

Analysis of particle size of the Ag-NP by dynamic light scattering (DLS) analyzer

The DLS measurement was performed to measure the particle size of the Ag-NP (Fig. 4). Observations revealed the homogeneous nature of the dispersed Ag-NP, with a size distribution between 20 and $58 \mathrm{~nm}$

\section{Analyses of the crystallinity of Ag-NP by XRD}

Crystalline nature of the NPs was confirmed by the XRD analysis. XRD measurement often proves to be a useful analytical tool for newly formed compounds and their phases. The XRD spectra of Ag-NP displayed four identical appearing at $2 \theta=38^{\circ}, 44^{\circ}, 64^{\circ}$, and $78^{\circ}$ conforming to the (111), (200), (220), and (311) facets of silver, respectively (JCPDS card file no. 04-0783) [10] (Fig. 5)

Investigation of elemental compositions of synthesized Ag-NP by EDX The analysis of the elemental composition of the green synthesized Ag-NP was made by EDX. As presented in Fig. 6, a sharp wide peak characteristic of silver was observed around 3-4 keV. The occurrence of a sturdy signal from Ag atoms $(81.54 \%)$ specified that the NPs were solely made by silver. Other EDX peaks such as $U$ and $O$ also suggested that they were mixed precipitates of the polysaccharide and silver salt. XRD analysis also agreed with the generation of nanosilver.

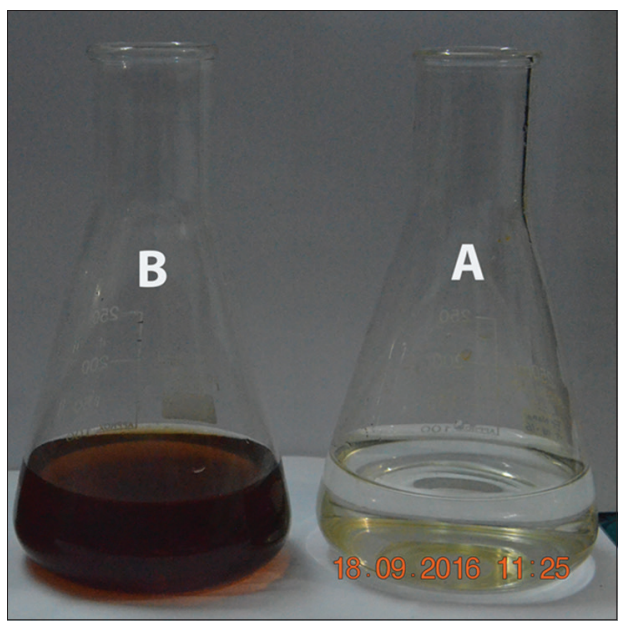

Fig. 2: (A) Only silver nitrate ( AgNO $_{3}$ ) solution and (B) color change of the reaction mixture of the polysaccharide with AgNO solution after $24 \mathrm{~h}$

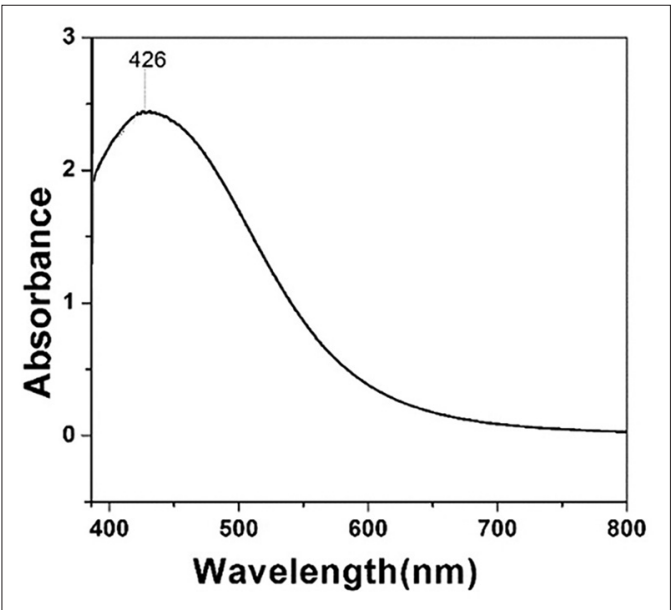

Fig. 3: UV-visible spectrum of the synthesized silver nanoparticles
FTIR analysis of isolated polysaccharide and biosynthesized Ag-NP Fig. 7 shows the FTIR absorption spectra for the polysaccharide and the synthesized Ag-NP, respectively. Both the spectra exhibited the occurrence of bands around $3430 / \mathrm{cm}, 2,910 / \mathrm{cm}, 1600 / \mathrm{cm}, 1450 / \mathrm{cm}$, and $1070 / \mathrm{cm}$ signifying the $\mathrm{O}-\mathrm{H}$ stretching, aldehydic $\mathrm{C}-\mathrm{H}$ stretching, $\mathrm{C}=$ C group, - COO stretching, and -C-O-C- stretching, respectively [37-40]. These peaks designated the existence of proteins and other organic

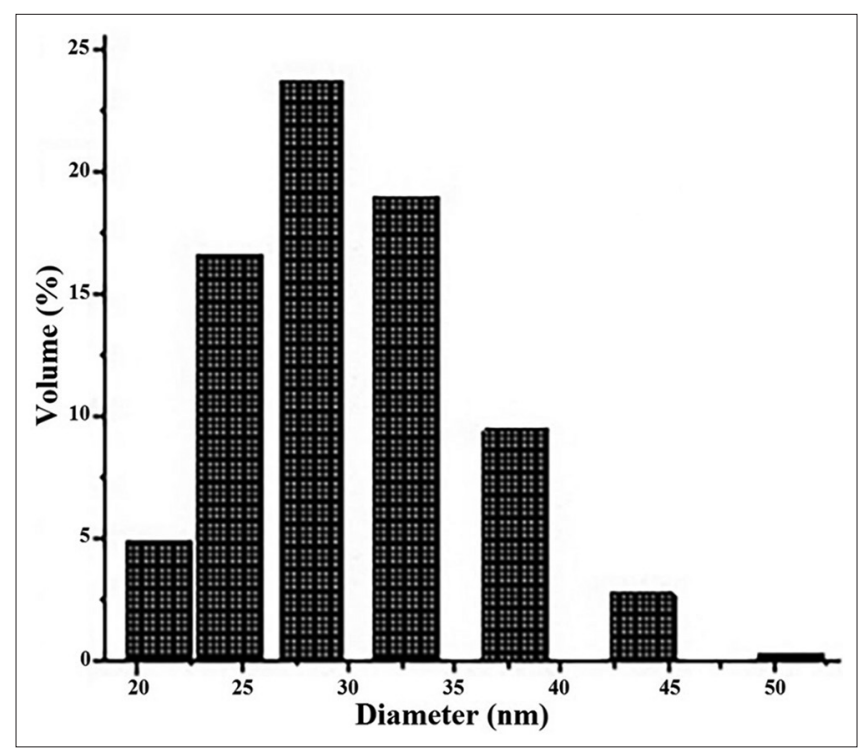

Fig. 4: The particle size distribution of bioreduced silver nanoparticles

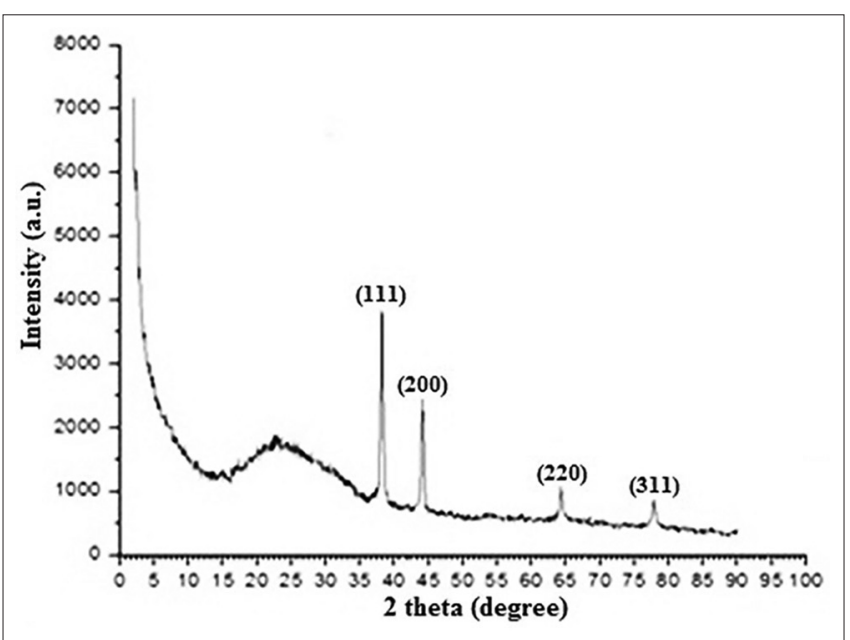

Fig. 5: Representative X-ray diffraction pattern of silver nanoparticles

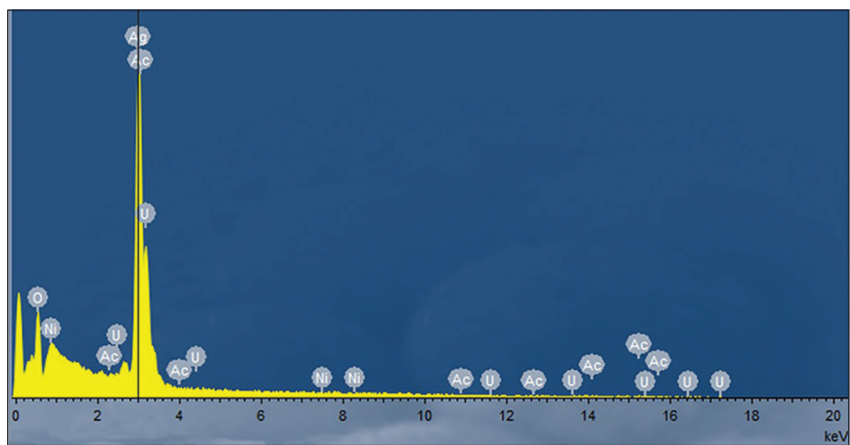

Fig. 6: Energy-dispersive X-ray spectrum of silver nanoparticles 
residues. Bands at around 1650,1550 , and $1250 / \mathrm{cm}$ indicated the amide I, II, and III linkages between the amino acid residues in proteins, which provided an indication in infrared regions of the electromagnetic spectrum [38,39,41]. Symmetric and antisymmetric modes of $\mathrm{C}-\mathrm{H}$ stretching were observed in the spectral region around 2920 and $2850 / \mathrm{cm}$, respectively [38]. The bands observed in the $500-750 / \mathrm{cm}$ spectral region indicated the occurrence of R-CH group [42].

\section{Transmission electron microscopic study of the Ag-NP}

Fig. 8a displays the TEM image of the Ag-NP with a diverse range of their sizes which were produced after the bioreduction of the $\mathrm{AgNO}_{3}$ solution by the polysaccharides. These findings inferred that the synthesized Ag-NPs were homogeneous and monodisperse in nature and most of them were spherical in shape. The diameters of these Ag-

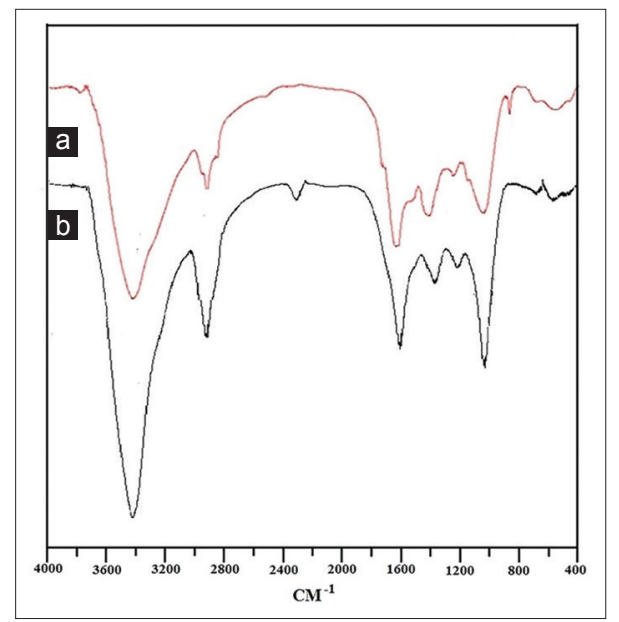

Fig. 7: Fourier-transform infrared absorption spectra of (a) isolated polysaccharide and (b) synthesized silver nanoparticles

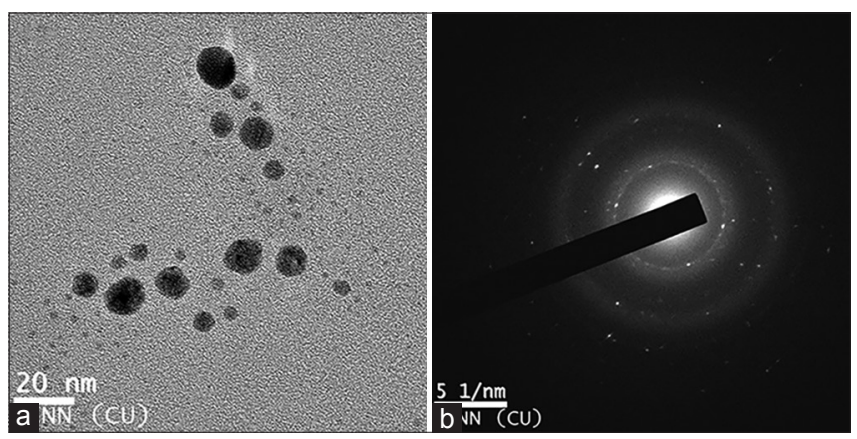

Fig. 8: (a) Transmission electron microscopic image of silver nanoparticles (Ag-NPs) (b) selected area electron diffraction patterns of crystalline Ag-NPs

Table 1: Antibacterial activity of synthesized silver nanoparticles as determined by minimum inhibitory concentration value $(\mu \mathrm{g} / \mathrm{ml})($ mean \pm standard deviation; $\mathbf{n}=3$ )

\begin{tabular}{llll}
\hline Type of bacteria & $\begin{array}{l}\text { Name of } \\
\text { bacteria }\end{array}$ & $\begin{array}{l}\text { Silver } \\
\text { nanoparticles }\end{array}$ & Streptomycin \\
\hline Gram-positive & $\begin{array}{l}\text { Listeria } \\
\text { monocytogenes }\end{array}$ & $62.77 \pm 11.74$ & $4.68 \pm 0.17$ \\
& $\begin{array}{l}\text { Staphylococcus } \\
\text { aureus }\end{array}$ & $179.24 \pm 29.38$ & $6.29 \pm 0.16$ \\
& $\begin{array}{l}\text { Bacillus subtilis } \\
\text { Escherichia coli }\end{array}$ & $174.05 \pm 33.56$ & $5.61 \pm 0.01$ \\
Gram-negative & $\begin{array}{l}\text { Salmonella } \\
\text { typhimurium }\end{array}$ & $123.42 \pm 10.69$ & $5.09 \pm 0.03$ \\
\end{tabular}

Streptomycin was considered as a positive control
NPs were in the range of 20-45 $\mathrm{nm}$. The average diameter was found to be $28 \pm 4 \mathrm{~nm}$. It was thought-provoking to note that majority of the NPs in the TEM image were not in physical contact but were separated by a fairly undeviating interparticle distance. Due to the developmental course of the sample preparation, the data obtained from the TEM and DLS measurements were quite different from each other. Although the particles were measured in the dry state in the TEM image, the actual diameter of the NPs was found in this analysis, whereas the size measured by the DLS experiment was in the hydrated state of the NPs. Therefore, the NPs had a higher hydrodynamic volume due to solvent effects in the hydrated state. The bright circular spots in the selected area electron diffraction pattern further confirmed the single crystalline nature of the Ag-NP (Fig. 8b) [43].

Analysis of the effect of polysaccharide-based Ag-NP on some pathogenic bacteria

The antibacterial activity of biosynthesized Ag-NP was observed against both Gram-negative and Gram-positive bacteria using the microdilution method. As presented in Table 1, the growth of all experimental strains was found to be affected in the presence of the NPs as compared to the negative control. In the case of L. monocytogenes, a Gram-positive bacterium, introduction of $50 \mu \mathrm{g} / \mathrm{ml}$ of polysaccharide Ag-NP caused $47.93 \pm 5.98 \%$ of reduction of bacterial density. Interestingly, growth of all examined Gramnegative bacteria was also detected to be inhibited in the presence of similar doses of the nanomaterials. Treatment of $50 \mu \mathrm{g} / \mathrm{ml}$ of synthesized nano inhibited $10.11 \pm 0.18$ and $28.17 \pm 5.97 \%$ in the case of E. coli and $S$. typhimurium, respectively. These observations suggested strong antibacterial potentiality of synthesized Ag-NP.

\section{CONCLUSION}

The present study described biosynthesis of stable Ag-NP using polysaccharide from fruits of $C$. decandra plant. The production of biosynthesized nanomaterial was established by UV-Vis, XRD, and FTIR. The green synthesized Ag-NP presented strong antibacterial activity against some pathogenic Gram-positive (L. cytomonogenes, B. subtilis, and $S$. aureus) and Gram-negative (S. typhimurium and E. coli) bacteria. Thus, the green synthesis of Ag-NP using plant polysaccharide was an environment-friendly and cost-effective method as compared to the conventional physical and chemical synthesis techniques.

\section{AUTHORS' CONTRIBUTIONS}

Gajendra Nath Maity, Joy Sarkar, Somanjana Khatua, Soumitra Mondal, and Krishnendu Acharya have equally contributed to the construction and editing of the manuscript.

\section{CONFLICTS OF INTEREST}

The authors confirm that they have no conflicts of interest.

\section{REFERENCES}

1. Rai M, Yadav A, Gade A. Silver nanoparticles as a new generation of antimicrobials. Biotechnol Adv 2009;27:76-83.

2. Mohammadlou M, Maghsoudi H, Jafarizadeh-Malmiri H. A review on green silver nanoparticles based on plants: Synthesis, potential applications and eco-friendly approach. Int Food Res J 2016;23:446-63.

3. Ydollahi M, Ahari H, Anvar AA. Antibacterial activity of silver-nanoparticles against Staphylococcus aureus. Afr J Microbiol Res 2016;10:850-5.

4. Ahmed S, Ahmad M, Swami BL, Ikram S. A review on plants extract mediated synthesis of silver nanoparticles for antimicrobial applications: A green expertise. J Adv Res 2016;7:17-28.

5. Zhao HQ, Aisa HA, Rasulov B, Rustamova N, Yili AR. Synthesis of Ag-NP on the basis of low and high molar mass exopolysaccharides of Bradyrhizobium japonicum 36 and its antimicrobial activity against some pathogens. Folia Microbiol 2016;61:283-93.

6. Bora T, Dutta J. Applications of nanotechnology in wastewater treatment - a review. J Nanosci Nanotechnol 2014;14:613-26.

7. Jain P, Pradeep T. Potential of silver nanoparticle-coated polyurethane foam as an antibacterial water filter. Biotechnol Bioeng 2005;90:59-63. 
8. Rajeshkumar SR. Synthesis of Ag-NP using fresh bark of Pongamia pinnata and characterization of its antibacterial activity against gram positive and gram negative pathogens. Resour Technol 2016;2:30-5.

9. Railean-Plugaru V, Pomastowski P, Wypij M, Szultka-Mlynska M, Rafinska K, Golinska P, et al. Study of silver nanoparticles synthesized by acidophilic strain of actinobacteria isolated from the of Picea sitchensis forest soil. J Appl Microbiol 2016;120:1250-63

10. Saha S, Sarkar J, Chattopadhyay D, Patra S, Chakraborty A, Acharya K, et al. Production of silver nanoparticles by a phytopathogenic fungus Bipolaris nodulosa and its antimicrobial activity. Dig J Nanomater Biostruct 2010;5:887-95.

11. Sarkar J, Dey P, Saha S, Acharya K. Mycosynthesis of selenium nanoparticles. Micro Nano Lett 2011;6:599-602.

12. Sarkar J, Ray S, Chattopadhyay D, Laskar A, Acharya K. Mycogenesis of gold nanoparticles using a phytopathogen Alternaria alternata. Bioprocess Biosyst Eng 2012;35:637-43.

13. Sarkar J, Ghosh M, Mukherjee A, Chattopadhyay D, Acharya K. Biosynthesis and safety evaluation of $\mathrm{ZnO}$ nanoparticles. Bioprocess Biosyst Eng 2014;37:165-71.

14. Sarkar J, Acharya K. Alternaria alternata culture filtrate mediated bioreduction of chloroplatinate to platinum nanoparticles. Synth React Inorg Met Nano Metal Chem 2017;47:365-9.

15. Sarkar J, Mollick MM, Chattopadhyay D, Acharya K. An ecofriendly route of $\gamma$-Fe2O3 nanoparticles formation and investigation of the mechanical properties of the HPMC- $\gamma$-Fe2O3 nanocomposites. Bioprocess Biosyst Eng 2017;40:351-9.

16. Dasgupta A, Sarkar J, Ghosh M, Bhattacharya A, Mukherjee A, Chattopadhyay D, et al. Green conversion of graphene oxide to graphene nanosheets and its biosafety study. PLoS One 2017;12:e0171607.

17. Acharya K, Sarkar J. Bryo-synthesis of gold nanoparticles. Int J Pharm Sci Rev Res 2014;29:82-6.

18. Kanchana R, Zantye P. Plant-mediated synthesis of silver nanoparticles with diverse applications. Asian J Pharm Clin Res 2016;9:124-8.

19. Joshi SC, Kaushik U, Upadhyaya A, Sharma P. Green technology mediated synthesis of silver nanoparticles from Momordica charantia fruit extract and its bactericidal activity. Asian J Pharm Clin Res 2017;10:196.

20. Watt J, Breyer-Brandwijk M. The Medicinal and Poisonous Plants of Southern and Eastern Africa. $2^{\text {nd }}$ ed. Edinburgh and London: E \& S. Livingstone Ltd.; 1962.

21. Kathiresan K, Ramanathan T. Medicinal Plants of Parangipettai Coast, Monograph. Parangipettai, India: Annamalai University; 1997.

22. Bandaranayake WM. Traditional and medicinal uses of mangroves. Mangroves Salt Marshes 1998;2:133-48.

23. Duke J, Wain K. Computer Index with more than 85,000 Entries. In: Medicinal Plants of the World. Vol. 3. Beltsville, Maryland: Plants Genetics and Germplasm Institute, Agriculture Research Service; 1981.

24. Banerjee D, Chakrabarti S, Hazra AK, Banerjee S, Ray J, Mukherjee B. Antioxidant activity and total phenolics of some mangroves in Sundarbans. Afr J Biotechnol 2008;7:805-10.

25. Uddin SJ, Shilpi JA, Barua J, Rouf R. Antinociceptive activity of Ceriops decandra leaf and pneumatophore. Fitoterapia 2005;76:261-3.

26. Nabeel MA, Kathiresan K, Manivannan S. Antidiabetic activity of the mangrove species Ceriops decandra in alloxan-induced diabetic rats.
J Diabetes 2010;2:97-103

27. Sakagami H, Kashimata M, Toguchi M, Satoh K, Odanaka Y, Ida Y, et al. Radical modulation activity of lignins from a mangrove plant, Ceriops decandra (Griff.) Ding Hou. In vivo 1998;12:327-32.

28. Vadlapudi V, Naidu K. In vitro antimicrobial activity Ceriops decandra against selected aquatic, human and phytopathogens. Int J Chem Tech Res 2009; 1:1236-8.

29. Ravikumar S, Gnanadesigan M, Suganthi P, Ramalakshmi A. Antibacterial potential of chosen mangrove plants against isolated urinary tract infectious bacterial pathogens. Int $\mathrm{J}$ Med Med Sci 2010;2:94-9

30. Chandrasekaran M, Kannathasan K, Venkatesalu V, Prabhakar K. Antibacterial activity of some salt marsh halophytes and mangrove plants against methicillin resistant Staphylococcus aureus. World J Microbiol Biotechnol 2009;25:155-60.

31. Mecozzi M. Estimation of total carbohydrate amount in environmental samples by the phenol-sulphuric acid method assisted by multivariate calibration. Chemometr Intell Lab Syst 2005;79:84-90.

32. Masuko T, Minami A, Iwasaki N, Majima T, Nishimura S, Lee YC, et al. Carbohydrate analysis by a phenol-sulfuric acid method in microplate format. Anal Biochem 2005;339:69-72.

33. Saha S, Khatua S, Paloi S, Acharya K. Antioxidant and nitric oxide synthase activation properties of water soluble polysaccharides from Pleurotus florida. Int J Green Pharm 2013;7:182-8.

34. Khatua S, Acharya K. Influence of extraction parameters on physicochemical characters and antioxidant activity of water soluble polysaccharides from Macrocybe gigantea (Massee) Pegler \& Lodge. J Food Sci Technol 2016;53:1878-88

35. Stojković D, Reis FS, Ferreira IC, Barros L, Glamočlija J, Ćirić A. Tirmania pinoyi: Chemical composition, in vitro antioxidant and antibacterial activities and in situ control of Staphylococcus aureus in chicken soup. Food Res Int 2013;53:56-62.

36. Sarkar J, Chattopadhyay D, Patra S, Deo SS, Sinha S, Ghosh M. Alternaria alternata mediated synthesis of protein capped silver nanoparticles and their genotoxic activity. Dig J Nanomater Biostruct 2011;6:563-73.

37. Jin L, Bai R. Mechanisms of lead adsorption on chitosan/PVA hydrogel beads. Langmuir 2002;18:9765-70.

38. Sanghi R, Verma P. Biomimetic synthesis and characterisation of protein capped silver nanoparticles. Bioresour Technol 2009;100:501-4.

39. Sathyavathi R, Krishna MB, Rao SV, Saritha R, Rao DN. Biosynthesis of silver nanoparticles using Coriandrum sativum leaf extract and their application in nonlinear optics. Adv Sci Lett 2010;3:1-6.

40. Socrates G. Infrared and Raman Characteristic Group Frequencies. $3^{\text {rd }}$ ed. Wiley Publisher; 2004.

41. Barth A. Infrared spectroscopy of proteins. Biochim Biophys Acta 2007;1767:1073-101.

42. Singh AK, Talat M, Singh DP, Srivastava ON. Biosynthesis of gold and silver nanoparticles by natural precursor clove and their functionalization with amine group. J Nanopart Res 2010;12:1667-75.

43. Mollick MM, Bhowmick B, Maity D, Mondal D, Roy I, Sarkar J, et al. Green synthesis of silver nanoparticles-based nanofluids and investigation of their antimicrobial activities. Microfluid Nanofluidics 2014; $16: 541-51$. 